\title{
Ciberespacinho: o discurso intersemiótico na literatura eletrônica infanto-juvenil
}

\author{
Penha Élida Ghiotto Tuão Ramos* \\ Analice de Oliveira Martins ${ }^{* * *}$
}

\section{Resumo}

Este estudo pretende verificar o impacto das novas tecnologias de informação e comunicação sobre os modos de produção e leitura do texto direcionado ao público infanto-juvenil, tendo em vista o surgimento de uma literatura inteiramente eletrônica e um discurso baseado no diálogo entre a palavra escrita e a palavra desenhada-sonorizada-animada. Para isso, será considerado o site da escritora e ilustradora mineira Angela Lago, angela-lago.net.br, especialmente o link denominado ciberespacinhomyoldhtmlsite, observando seu discurso intersemiótico e a apropriação de recursos hipertextuais potencializados pela tecnologia digital. Notou-se que o suporte eletrônico não extrai os aspectos literários do texto, mas ocasiona o emprego de uma linguagem híbrida, potencialmente hipermidiática, que se incorpora à gênese do texto sem limitar as atualizações a serem feitas pelo leitor.

Palavras-chave: Literatura. Leitor. Tecnologias. Recepção.

\section{Introdução}

$\mathrm{O}$ armazenamento do texto em formato digital elimina a noção de volume tão característica do livro impresso e torna possível o emprego de recursos até então inimagináveis. Há agora o acesso a textos a partir de links, a inserção de imagens animadas, a abertura de outras janelas enquanto se lê ou faz um registro. Enfim,

\footnotetext{
Mestranda no curso de Pós-Graduação em Cognição e Linguagem da Universidade Estadual do Norte Fluminense Darcy Ribeiro (UENF). Atua na linha Pesquisas Interdisciplinares em Comunicação, Educação e Novas Tecnologias da Informação. E-mail: elidatuao@hotmail.com

** Doutora em Estudos de Literatura pela PUC-RIO. Professora colaboradora do Programa de Pós-Graduação em Cognição e Linguagem da Universidade Estadual do Norte Fluminense Darcy Ribeiro (UENF). Áreas de interesse: Literatura Brasileira, Teoria da Literatura, Estudos Culturais, Linguagem e Novas Tecnologias da Comunicação. E-mail: analice.martins@terra.com.br
}

Data de submissão: jul. 2014 - Data de aceite: ago. 2014 http://dx.doi.org/10.5335/rdes.v10i2.4133 
[...] com a tela substituta do códex, a transformação é mais radical, pois são os modos de organização, de estrutura, de consulta ao suporte do escrito que se modificaram (CHARTIER, 1999, p. 98).

Entretanto, é facilmente verificável que a linguagem escrita mantém-se como eixo da comunicação e da produção textual on-line: "Os autores não escrevem livros: não, eles escrevem textos que se tornam objetos escritos, manuscritos, gravados, impressos e, hoje, informatizados" (CHARTIER, 1999. p. 17). Com a expansão da internet e a proliferação do hipertexto, a forma dada ao texto ganha papel crucial e revolucionário, pois se torna possível deslocar-se de um texto a outro sem sair do lugar onde se está: "[...] o leitor pode escolher, através da navegação, o que quer ler" (SCHITTINE, 2004, p. 78).

No curso das evoluções tecnológicas, também se encontram os textos literários, os quais, por vezes, são digitalizados e dispostos em sites que mais se assemelham a imensas bibliotecas; em outros casos, textos são produzidos especificamente nos - e para - espaços virtuais. A internet oferece novos materiais de leitura carregados de possibilidades de difusão e manipulação que estabelecem entre o leitor e o texto uma relação na qual quem lê também pode ser coautor.

Com a proposta de oferecer aos leitores uma leitura interativa, a escritora Angela Lago apresenta não só produções impressas, mas também aquelas geradas em espaços digitais, trazendo aos jovens leitores de literatura infantil uma nova opção de suporte textual: a tela digital. Não se trata propriamente da substituição de um suporte por outro, mas da coexistência de ambos, cada qual com sua textualidade ou hipertextualidade. Junto ao novo suporte, um novo texto também surge enquanto resultado de uma constituição multimodal, em que "aspectos verbais e pictoriais se complementam de tal forma que a ausência de um deles, mesmo sendo de menor incidência, afeta a unidade global do texto" (DIONÍSIO, 2008, p. 134).

Diante desse contexto, algumas questões inquietam e merecem reflexão, especialmente no que tange à linguagem utilizada nos textos que compõem a literatura do ciberespaço e a recepção que lhe é dada. Assim, quais são as particularidades da linguagem que compõe a literatura eletrônica? Qual a distinção entre a enraizada literatura digitalizada e a ascendente literatura digital? Que aspectos relacionados à recepção estética são relevantes?

A fim de indicar possíveis respostas, ainda que inconclusas, será feita uma análise do site da premiada escritora e ilustradora mineira Angela Lago, tomando como referência seu link-livro chamado ciberespacinhomyoldhtmlsite.

\section{Angela Lago: a escrita de um anjo endiabrado}

Em apontamentos a respeito de o que seria a figura do autor e dos locais onde sua função é exercida, bem como da 
relação de atribuição à qual está sujeito, Michel Foucault (2009, p. 83) afirma que "o autor é, sem dúvida, aquele a quem se pode atribuir o que foi dito ou escrito". Nessa condição de quem escreve e é reconhecido como tal, está a escritora e ilustradora Angela Lago, uma verdadeira encantadora de palavras e imagens.

Angela nasceu em Belo Horizonte, em 1945, e dedica-se há mais de 30 anos à literatura infantil. Trata-se de uma premiada autora, no Brasil e no exterior, homenageada pelo prêmio Jabuti 2000 na categoria de Melhor Livro Infantil Juvenil. A artista utiliza as tecnologias de seu tempo em prol de uma literatura que dialogue com o universo infantil dos nativos digitais - geração de jovens nascidos a partir das tecnologias digitais, conforme alcunha Marc Prensky (2001). Suas obras trazem a proposta de associar a brincadeira ao aprender e, por isso, são impressos e não dispensam ilustrações muito bem dissolvidas nas narrativas não como antecipação do texto verbal, mas como parte da história.

Mesmo portando um nome literalmente angelical, a autora refere-se a ele de um modo totalmente paradoxal em seu site www.angela-lago.com.br, no link biográfico angelita-del-lagoangela-lagoangel-lake: "Não sei por que resolveram me chamar de anjo. Este diabo de nome me dá um trabalho que vocês nem imaginam". Certamente um comentário curioso, mas que bem revela as travessuras que a escritora realiza em seus textos com toda a sua inventividade. Um exemplo disso, acontece quando Angela rompe os limites consagrados pela literatura impressa e utiliza um site para contar algumas histórias, dando um novo formato aos seus textos e proporcionando novas experiências aos jovens leitores. Talvez pela ousadia em acreditar que os aparelhos eletrônicos possam constituir um elemento a mais nas relações estabelecidas entre leitor e literatura, Angela tenha maior aproximação com uma figura endiabrada do que com uma celestial - o que fica ainda mais claro quando se leva em conta a sua produção artística, a qual tanto ultrapassa quanto contraria a expectativa do leitor por meio da mistura de sistemas semióticos.

Sempre envolvendo o leitor, a autora faz não só um convite à leitura, mas também à brincadeira, o que surpreende por não resultar em uma leitura facilitada. Ao contrário, o que se percebe nos impressos de Ângela é uma linguagem mista capaz de provocar o leitor - o que, em seu site, é potencializado pela tecnologia digital. Em rede, a escrita de Angela Lago estabelece horizontes textuais norteados pela hipertextualidade e pautados pela hipermidialidade, gerando um discurso intersemiótico.

\section{Fundamentos teóricos}

\section{Da literatura impressa à digital}

$\mathrm{Na}$ evolução do suporte textual, o rolo persistiu por longo tempo, sendo um dispositivo de leitura que, pelo seu formato, reproduzia a linearidade da 
fala. Com a implantação de um novo suporte, o códex, com suas folhas reunidas em caderno, a disposição do texto sobre superfície sofre uma fragmentação recorrente da distribuição do texto em páginas. Na sua evolução mais recente, o texto escrito se dilui no formato digital e amplia sua difusão:

Sem materialidade, sem localização, o texto em sua representação eletrônica pode atingir qualquer leitor dotado do material necessário para recebê-lo. [...] Todo leitor, onde estiver, sob a condição de estar diante de um visor de leitura conectado à rede que assegura a distribuição de documentos informatizados, poderá consultar, ler, estudar qualquer texto, independente de sua localização original (CHARTIER, 1999, p. 104).

Nesse curso, está a produção literária difundida no ciberespaço ou influenciada por ele. Assim como o suporte textual se modificou, também o modo de produção e o próprio texto se alteraram, e, consequentemente, a literatura. À dimensão artística tão intrínseca à Literatura, agrega-se a dimensão computacional, na qual "a palavra deixa de ser linguagem verbal e amplia seus horizontes, suas delimitações, para tornar-se texto verbal, sonoro, visual, audiovisual, digital, em outro contexto" (ANTONIO, s.d).

No Século XXI, as obras são escritas, editadas, compostas e enviadas aos computadores que as converterão em livros, não restando qualquer estranhamento à afirmação de que a literatura contemporânea é computacional - como indica a pesquisadora e crítica literária Katherine Hayles (2009, p. 61). Assim, quase todos os livros impressos são, antes de tudo, arquivos digitais, ainda que esse caráter computacional fique mais aparente na literatura eletrônica. Cresce a produção de literatura eletrônica, do mesmo modo que se aprimora a manifestação da eletrônica na literatura. Com isso, a literatura impressa arma-se de estratégias para "atender as expectativas de um público assentado no mundo digital" (CARVALHO, 2010, p. 155).

No site, o escritor oferece uma interatividade que permite liberdade ao leitor. Enquanto no impresso há uma ordem um tanto quanto rígida de apresentação do texto, no ciberespaço, o leitor não só está autorizado a dar a sua linearidade ao texto lido, como está estimulado a isso. A escrita se oculta em camadas interpostas que são desvendadas conforme os cliques dados; a ordem previamente determinada pelo autor se mostra mais frágil no texto digital do que no impresso:

O leitor da leitura na Internet encarna o papel do detetive auditivo que lê as pistas do hipertexto, que segue as linhas e que estabelece uma relação plausível entre os vários seguimentos do texto. Em vez de seguir apenas os links fornecidos, o leitor-detetive também tem de procurar e encontrar os missing links. Não pode confiar. Na estrutura linear do link do hipertexto, tem de decifrar a ligação secreta, as estratégias discursivas e restabelecer a ligação temática das presunções auditivas a partir do tópico, servindo-se do seu instinto de detetive. A audição alcançada sobre uma trama labiríntico / risomática do nosso saber universal enciclopédico visa a uma ordem das coisas provisória e hipotética (VILLAÇA, 2002, p. 109).

Em angela-lago.net.br, a literatura infantil já comungada com as ilustrações nos impressos ganha elementos possíveis 
somente com a tecnologia digital. Assim, além do livre uso de cores e ilustrações, 0 som e o movimento se unem às palavras, agregando à literatura infantil uma nova linguagem, gerando novas formas de manifestação para uma literatura por muito tempo esquecida. A literatura dirigida ao público infantil só se expande a partir da década de 1970, época em que ficou facultada à escola a introdução de obras e autores contemporâneos:

A literatura infantil se constituiu uma das principais beneficiárias da nova metodologia adotada, expandindo a produção e circulação em proporções até então desconhecidas (ZILBERMAN, 2009, p. 15).

Quando se trata da linguagem usada na estrutura do site de Angela Lago, entra em questão a atenção exigida do leitor para a leitura-navegação proposta. Logo que o site é acessado, abre-se uma tela vermelha com um retângulo preto ao centro. Na parte superior, em linha branca como o risco de giz, estão nome e sobrenome da autora: Angela Lago. Como mágica, eles se desmaterializam diante do leitor de modo que o nome Angela se transforma em um anjo e a palavra Lago retoma seu sentido denotativo e inunda o anjo, fazendo-o desaparecer. Assim, os recursos tecnológicos a alteram construção do texto. Interessante observar que não há uma sucessão de imagens que antecipam a leitura do texto verbal; o que prevalece a todo tempo são imagens que se integram à escrita, compondo um hibridismo linguístico singular para o texto literário.
Enquanto carrega a página do site, números fantasiados de animais saltitam na tela informática até que, enfim, emergem as janelas linkadas que tornarão possível o acesso ao texto e o pequeno leitor-navegador poderá escolher qual caminho trilhar: se acompanhará Chapeuzinho Vermelho, o cão esquelético ou o ABCD personalizado. Há ainda o acesso ao ciberespacinho - ou ciberespacinhomyoldhtmsite, como aparece na abertura do site de Angela Lago -, a informações sobre a autora e a uma amostra de seus livros impressos - além de um espaço reservado aos professores. Tudo isso sob uma introdução sonora que se altera conforme o rumo escolhido.

Figura 1: Tela inicial do site de Angela Lago

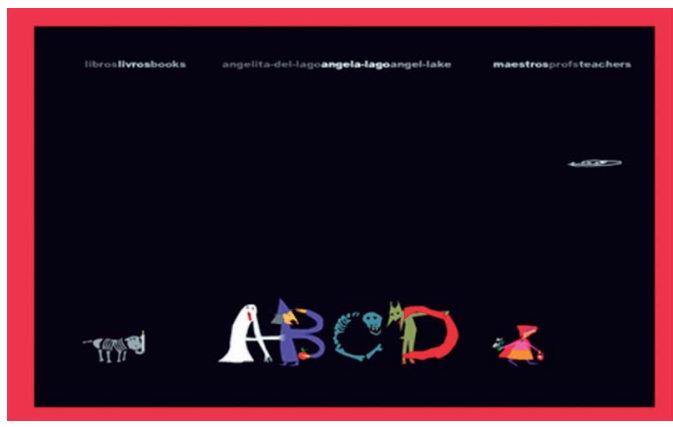

Fonte: http://www.angela-lago.net.br/.

Em princípio, apenas uma tela preenchida com algumas imagens sonorizadas, mas que, a cada clique, desencadeia uma nova situação de leitura, por vezes pautada somente em imagens - o que não soa muito estranho quando se trata de uma escritora que também é ilustradora. Cada imagem da página principal é temática de alguma atividade interativa 
e remete o leitor a outras dimensões textuais por meio de hiperlinks, o que confere grande velocidade na sobreposição das páginas:

Os hipertextos servem para interromper o fluxo de leitura através de redes remissivas interligadas, os links, e para conduzir o leitor a um vertiginoso delírio de possibilidades (VILLAÇA, 2002, p. 107).

É certo que as conexões proporcionadas pelos links não estão restritas ao contexto informático. Há tempo que os textos impressos fazem o uso de notas de rodapé e de palavras remissivas, as quais requerem conhecimento extra e intratextual que implicam uma atividade de busca por parte do leitor. Na verdade, o que de fato se efetiva é que os recursos tecnológicos digitais aprimoraram a uterina proposta do hipertexto, permitindo ao leitor a obtenção de informações relevantes sob uma velocidade indiscutível, o que dispensou os deslocamentos físicos; não há a necessidade de se dirigir a uma biblioteca, nem de acumular volumes de livros:

Com o hipertexto e as múltiplas janelas das telas, a operação se torna fácil e provoca um novo modo de ler. O prototexto se torna parte integrante do texto, que surge assim mais como um processo em curso de elaboração do que como uma obra definitiva. De resto, as novas capacidades de armazenamento modificam o estatuto da nota de rodapé de páginas e das referências cruzadas. Não há mais necessidade de buscar o texto citado pelo autor em uma edição que se tornou inencontrável. Pode-se ter acesso a ela diretamente e ler grandes trechos, ou até mesmo - por que não? - sua integridade (CLÉMENT, 2003, p. 32).
No site de Angela Lago, a página principal funciona como um sumário plano e desierarquizado, mediado por ilustrações que, a partir de cliques, possibilitam a localização exata da leitura pretendida ou seria da interação não pretendida, já que o leitor não sabe exatamente aonde vai chegar? O leitor visualiza a história a ser lida e, com os recursos digitais, ouve e participa. Tem-se, então, uma narrativa visual e auditiva, que mescla palavras, imagens e sons, não se descartando da tela digital $o$ ato da leitura da palavra:

$\mathrm{O}$ fato inconteste é que a Internet e todos os gêneros a ela ligados são eventos textuais fundamentalmente baseados na escrita. $\mathrm{Na}$ Internet, a escrita continua essencial apesar da integração de imagens e de som (MARCUSCHI, 2005, p. 19).

Ao transitar entre a literatura impressa e a digital, Angela Lago oferece aos leitores uma escrita materializada por meio do artefato livro e outra desmaterializada a partir da virtualidade informática. Tem-se um texto real, mas não palpável como antes; ao contrário de qualquer afastamento, a ausência de um suporte tocável não cria distância entre o material escrito e o leitor, mas encurta espaços:

A desmaterialização, ao abolir a duração, abole a distância; convoca espaços até então longínquos, temporalmente distantes, porque a distância entre lugares mede-se sempre pelo tempo (do percurso). Assim, toda a temporalização que se joga na escrita transforma-se, subitamente, numa questão cartográfica (BABO, 2003, p. 106). 


\section{Hipertexto: o texto em flashes}

Clicando no link ciberespacinhomyoldhtmlsite, o leitor é remetido a uma página secundária do site de Angela Lago, na qual um ser verde e saltitante brinca de equilibrista sobre um pequeno planeta com uma casinha amarela de telhado vermelho. Em sua órbita, o nome de algumas línguas - como a portuguesa, a espanhola e a inglesa - surgem e desaparecem rapidamente, sendo dada ao leitor a tarefa de novamente pressionar o cursor sobre uma das palavras que emergem aos seus olhos e definir em qual idioma pretende ler o texto que posteriormente terá acesso. Ao dar essas opções, a autora demonstra a abrangência do texto disposto no ciberespaço. Ora, se para o texto em rede não há fronteiras, por que oferecê-lo apenas em língua portuguesa? É certo, então, que "as características virtualizante e desterritorializante do ciberespaço fazem dele o vetor de um universo aberto" (LÉVY, 1999, p. 50).

Estabelecendo uma brincadeira, o personagem do ciberespacinho diz que tem uma surpresa e o leitor-explorador precisa interagir com ele clicando em uma das mensagens que se sucedem, as quais indicam ora uma mão do alienígena ora outra: “Nesta mão não!”, "Nesta mão não! Não na outra!", "Nesta mão não! Na outra!". Com essa estratégia, imagem e palavra dialogam tendo como artifício uma sucessão de movimentos que conferem ao texto uma nova plasticidade:
Figura 2: Alienígena, personagem de ciberespacinho

TENHO UMA SURPRESA...

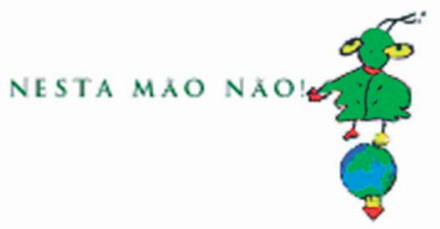

Fonte: http://www.angela-lago.net.br/.

Após o clique, uma nova comunicação: "Esta é minha mão suicida! Depressa, escolhe outra!". Então, a partir de um pronome demonstrativo e de um advérbio de negação que aparecem em torno do alienígena, sugestões são dadas sobre qual mão escolher: "Esta", "Não!". Feita mais uma incursão, aparece ao leitor uma nova e surpreendente mensagem: "Esta é minha mão borracha de apagar!" - e, de fato, a imagem do pequeno ser verde começa a se desintegrar até sumir por completo, não importando o que fizesse o leitor.

Então, a última opção é dada ao leitor para salvar o extraterrestre: clicar em "Aqui!". Entretanto, caso demore no socorro, o ciberpersonagem esverdeado desaparece por completo, restando apenas o planeta em azul e verde, no qual a casinha, até então, em segundo plano passa a ocupar o topo do globo e ganha um sorriso que a põe em destaque. Além disso, em relação ao tamanho do planeta, a casinha está desproporcionalmente evidenciada - o que faz lembrar o Pequeno Príncipe em seu planeta-asteroide B612 - e apela pela atenção do leitor: 
Figura 3 - Casinha ganha destaque

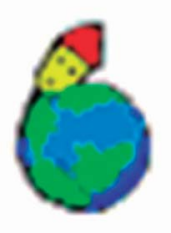

\section{AQUI!}

Fonte: http://www.angela-lago.net.br/.

Após essa sequência de cliques, vem à tona um texto em que predomina a linguagem verbal e o uso de hiperlinks. Nele há um eu que agradece ao leitor por ter sido salvo:

Figura 4 - Poema marcado por hiperlink

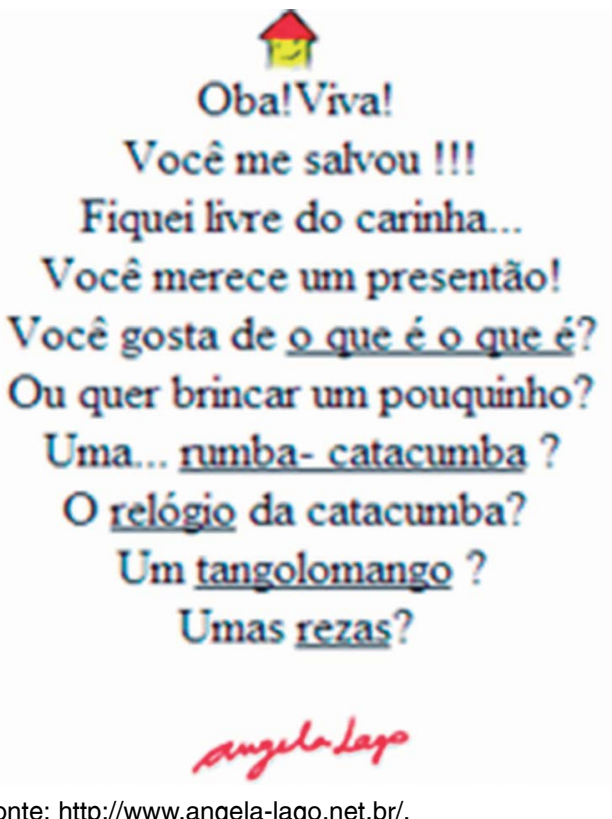

Considerando que o extraterrestre que se comunicava diretamente com o leitor foi totalmente apagado, quem faz o agradecimento nesse texto-planeta? A quem pertenceria a voz que anuncia "Fiquei livre do carinha..."? Certamente, surge um nó para o leitor desatar. Tendo em vista que a casinha continua sorridente e elevando-se na parte superior do texto que parece substituir o planetinha - até então a base para a casinha -, é possível levantar a hipótese de que ela estaria comemorando por ficar livre do carinha que, afinal, era o extraterrestre, um invasor. Tem-se, assim, uma constituição multimodal em que o texto só existe na diversidade semiótica, aqui representada pela palavra e pela imagem - e certamente enriquecida pela animação. Então, ao somar palavras e as imagens, Angela Lago une a significação linguística com a própria realidade, confirmando que o emprego de um vocábulo não é casual; somando-o a uma imagem, estaria também estabelecendo contato entre a significação linguística e a própria realidade concreta, sem, é claro, explicitar isso para o leitor:

Ao escolher a palavra, partimos das intenções que presidem ao todo do nosso enunciado, e esse todo intencional, construído por nós, é sempre expressivo. E esse todo que irradia sua expressividade (ou melhor, nossa expressividade) para cada uma das palavras que escolhemos e que, de certo modo, inocula nessa palavra a expressividade do todo. [...] apenas o contato entre a significação lingüística e a realidade concreta, apenas o contato entre a língua e a realidade - que se dá no enunciado - provoca o lampejo da expressividade (BAKHTIN, 1997, p. 311). 
Ora afirmar que esse não é um texto literário ou que se trata de uma leitura facilitada pela tecnologia seria um equívoco. Angela Lago demonstra profunda preocupação com a produção de sentido e a interpretação do texto produzido, sem fazer com que o texto perca a sua textualidade em função da interação oriunda dos recursos digitais:

A interpretação, isto é, a produção do sentido, doravante não remete mais exclusivamente à interioridade de uma intenção, nem a hierarquias de significações esotéricas, mas antes à apropriação sempre singular de um navegador ou de um surfista. O sentido emerge de efeitos de pertinência locais, surge na intersecção de um plano semiótico desterritorializado e de uma trajetória de eficácia ou prazer. Não me interesso mais pelo o que pensou um autor inencontrável, peço ao texto para me fazer pensar, aqui e agora. A virtualidade do texto alimenta minha inteligência em ato (LÉVY, 1996, p. 49).

Tem-se, assim, que é preciso compreender o quanto os recursos dispostos no computador contribuem para a potencialização da produção textual e, consequentemente, para a leitura na tela, pois

considerar o computador apenas como um instrumento a mais para produzir textos, sons ou imagens sobre o suporte fixo (papel, película, fita magnética) equivale a negar sua fecundidade proporcionalmente cultural, ou seja, novos gêneros ligados à interatividade (LÉVY, 1996, p. 41).

Em ciberespacinho, o que importa não é o contato com o suporte tela, mas as possibilidades de leitura que são lançadas por meio do hipertexto e do hibridismo semiótico de modo a intensificar a relação entre leitor e texto. $\mathrm{O}$ hipertexto estabelece nós que remetem a outros textos e autores; mescla o texto escrito com as imagens, sons e animações, conferindo, assim, uma dinamicidade nunca vista. Trata-se de uma nova formatação textual que atribui à leitura diferentes percursos, originando uma atividade altamente atrativa para a geração de nativos digitais. Dessa forma, o texto sai da estaticidade: "[...] está mais próximo do próprio movimento do pensamento" (LÉVY, 1996, p. 48). Conforme o hiperlink selecionado em ciberespacinho, uma leitura diferente se abre juntamente com uma nova página-tela, a qual pode variar seus temas entre: o que é, o que é?, rumba-catacumba, relógio, tangolomango e rezas.

Em tangolomango uma novidade ao leitor: "Quem souber uma versão/de tangolomango,/ou tango-lo-mango, ou tango-mango,/mande para mim,/que eu coleciono!". Isso significa que o leitor tem a oportunidade de também ser autor. Hipertextualmente, quando clica em mande para mim, o leitor é levado ao outlook para digitar e enviar seu texto. A autora Angela Lago ainda complementa dizendo: "Das versões que chegaram, separei uma deliciosa para você". Através do link uma, um leitor terá acesso ao texto enviado por outro leitor e que, nesse processo retroalimentar, se torna também um coautor. Invertem-se, assim, papéis de autor e leitor. Um novo espaço e uma nova forma de fazer literatura revelam-se na era digital.

Tal procedimento evidencia o que Lévy denomina de Efeito Moebius: 
"passagem do interior ao exterior e do exterior ao interior" (LÉVY, 1996, p. 24). $\mathrm{O}$ autor como entidade distante e pouco acessível se torna próximo do leitor e, muitas vezes, converte-se também ao papel de leitor. Por conseguinte, aquele que, tradicionalmente, só tem acesso ao texto previamente determinado e sequenciado pelo autor, passa a ser coautor e dá suas direções ao texto, concluindo-o.

$\mathrm{O}$ hipertexto equivale a um indicador de percurso para leituras possíveis:

O navegador participa, portanto, da redação do texto que lê. Tudo se dá como se o autor de um hipertexto constituísse uma matriz de textos potenciais, o papel dos navegantes, sendo o de realizar alguns desses textos colocando em jogo, cada qual à sua maneira, a combinatória entre os nós (LÉVY, 1999, p. 57).

Sendo o hipertexto um operador da virtualização do texto, cabe ao leitor a sua atualização, a qual aparece, então, como "a solução de um problema, uma solução que não estava contida previamente no enunciado. A atualização é criação, invenção de uma forma a partir de uma configuração dinâmica de forças e de finalidades" (LÉVY, 1996, p. 16).

Por se tratar de conteúdos de literatura infantil, nos livros impressos de Angela Lago é frequente o uso de uma linguagem multimodal e no site essa mistura recebe novos elementos: sons e movimentos. Isso resulta em um texto que exige do leitor uma capacidade de manipulação e transformação das informações que se despontam na tela para, então, provocar a sua interpretação:
A atualização aparece então como a solução de um problema, uma solução que não estava contida previamente no enunciado. A atualização é a criação, invenção de uma forma a partir de uma configuração dinâmica de forças e finalidades (LÉVY, 1996, p. 16).

A literatura em tela digital exige, de seu receptor, procedimentos típicos da leitura, assim como o livro impresso, e o navegador que não possui a perspicácia de leitor não se mostra capaz de atualizá-la.

$\mathrm{O}$ uso de recursos hipertextuais deu origem a um novo trato à linguagem e, consequentemente, a um novo texto: "A Internet surge como metáfora das teorias literárias pós-modernas: de um lado, pela noção de hipertexto como mapa rizomático interligado e, por outro, pela noção de hipertexto como texto aberto, que só existe pelo ato de leitura" (VILLAÇA, 2003, p. 108). No ciberespaço há velocidade, manipulação de informações e descoberta de regras não explícitas tudo por meio de uma exploração que não deixa de ser textual.

\section{O atar e o desatar dos nós da atualização}

Na leitura, é essencial que ocorra a convergência entre leitor e texto, que se estabeleçam intervenções capazes de desatar os nós textuais, preenchendo seus lugares vazios ou, em outras palavras, provocando a recepção estética. Apenas decodificar o texto, não resolve as questões relativas à atualização, do mesmo modo que, na leitura-navegação do ciberespaço, 
os saltos de link em link, de hipertexto em hipertexto, não garantem a compreensão:

[...] uma leitura proveitosa do hipertexto exige um maior grau de conhecimentos prévios e maior consciência quanti ao buscado, já que é um permanente convite a escolhas muitas vezes inconsequentes (MARCUSCHI, 2000, p. 94).

Em se tratando de um texto digital que apresenta caráter literário e, por isso, se identifica como literatura eletrônica, é possível afirmar que sua leitura exigirá do leitor ainda mais acuidade, pois, somada às artimanhas literárias estarão os dispositivos dos meios eletrônicos (hiperlinks, hipertextos e hipermídia) - como é possível verificar no site de Angela Lago. O funcionamento do hipertexto, bem como a própria organização do texto digital em geral, deveria contribuir para o melhor desempenho do leitor, pois facilita tanto os avanços quanto os retrocessos na atividade de leitura: basta que sejam dados cliques para que o texto se desdobre sob as intenções do leitor. Assim, o leitor assume uma mobilidade incomparável àquela oferecida pelos rituais analógicos do texto impresso. Contudo, o avanço indiscriminado pelos links é altamente sedutor, tornando-se irresistível a ponto de condicionar os leitores ao dandismo pelo ciberespaço: "O leitor seria um dândi ou um detetive informático para navegar na leitura na Internet, ou seja, leitura orientada hipertextualmente" (VILLAÇA, 2002, p. 108).

Esse fascínio que pode impulsionar o leitor aos cliques sem propósito seria ainda uma resposta à própria função do hiperlink, que é chamar a atenção do leitor e despertar sua curiosidade a respeito do conteúdo ocultado. O hiperlink funciona como uma fonte de informação ágil e prática - o que também facilita $o$ seu acesso:

Do ponto de vista cognitivo, pode-se dizer que o hiperlink exerce o papel de "encapsulador" de cargas de sentido, capaz de gerar no leitor o desejo de seguir os caminhos indicados. Cabe-lhe acionar os modelos que o hiperleitor tem representados na memória com o intuito de desafiá-lo a conferir o que existe por trás deles, já que, antes de mergulhar nos hiperlinks, o leitor formula mentalmente uma série de hipóteses sobre o que poderá encontrar; ou seja, antes mesmo de acionar o mouse, o leitor vai fazer inferências sobre o conteúdo central com que se vai defrontar ao seguir essas pontes virtuais (KOCH, 2005, p. 66).

A velocidade e a fragmentação do hiperlink podem ser aproximadas à dinâmica da realidade pós-moderna ou pós-humana, segundo conceituam alguns autores com Santaella (2003, p. 31), ao se referirem ao contexto contemporâneo e às relações entre homens e máquinas. O texto disponibilizado no ciberespaço torna a leitura uma tarefa ainda mais complexa, já que a descentralidade ocasionada pelo hipertexto exige atenção redobrada do leitor frente à tela:

O hiperlink potencializa a lógica de uma coisa E outra ao mesmo tempo, por isso não há centro nos Hipertextos, nem há um Hipertexto central ao qual se deve prestar alguma obediência (XAVIER, 2002, p. 161, grifo do autor).

Outro elemento que amplia as possibilidades de atualização do texto eletrônico é a interatividade conferida pelos 
hiperlinks, visto que o leitor poderá ou não acessá-los - ou ainda, optar entre um link e outro -, traçando, dessa forma, diferentes caminhos para a leitura. Esse, no entanto, é um fator que também poderá impedir a atualização, caso o leitor não consiga reestabelecer a compreensão após as sucessivas rupturas cognitivas acarretadas pela hiperleitura. Há, assim, um aumento das chances de dispersão do leitor, podendo esse se desnortear de seus objetivos de leitura e de sua concentração, o que impedirá o processo de atualização:

\begin{abstract}
A interatividade proporcionada pela tecnologia é uma das questões mais exploradas, o que supõe um leitor de nível privilegiado em termos de conhecimento e criatividade. O perigo é que, em se tratando de um infoleitor, as possibilidades do hipertexto se percam. Nem mesmo a função de detetive lhe será adequada. Por outro lado, a produção on-line tem, muitas vezes, apenas a pretensão de veicular o produto, ou de aceitar pequenas intervenções do leitor, o que descaracteriza também as vantagens do novo meio (VILLAÇA, 2002, p. 111).
\end{abstract}

A construção do texto digital se dá a partir de recursos semióticos diversos daqueles convencionalmente utilizados no texto impresso. No ciberespaço, a linguagem normalmente é híbrida e, para que ocorram atualizações, o leitor necessariamente terá que ser eficiente nas interconexões que virá a estabelecer no texto, apreendendo as metáforas da literatura digital. Nessa perspectiva, a leitura meramente decodificante manterá os sentidos do texto virtualizados e nenhuma construção nova será alcançada, como ocorre, inclusive, nos textos impressos e na leitura linear.
Ainda que paradoxal, pode-se dizer que a leitura é uma ação una e múltipla. Não perde os caracteres que fazem dela uma ação específica, determinada e reconhecida como tal - por isso, una; mas, ao mesmo tempo, se aplica a situações várias - sendo, portanto, múltipla. A leitura pode atuar sobre imagens, sons ou palavras - ou em todas essas matrizes simultaneamente -, não importando o suporte utilizado. Nela, sobrepõe-se um comportamento investigativo que busca a compreensão, isso é, o desatamento de nós. O que certamente oscilará é o modo como essa investigação se dará, seja pelas estratégias subjetivamente determinadas pelo leitor ou por aquelas necessariamente exigidas pelo próprio texto e seu suporte. Não se leu o códex como se leu um pergaminho; do mesmo modo, não se lê o texto eletrônico da mesma forma que o texto impresso. São alterados - até mesmo, radicalmente - os modos de leitura firmados pelas convenções impressas de mais de quinhentos anos e, com isso, a sensação de que ler na tela seja uma ação dinâmica e interativa associada à perda da morosidade por séculos cultivada pelos impressos.

\section{Literatura eletrônica e recepção estética}

Tão importante quanto aquele que escreve o texto, é aquele que o lê. Sob a direção do leitor está o rumo a ser dado ao texto; dele dependem a identificação dos elementos textuais e a sua compre- 
ensão. É o leitor que pactua ou não com o texto para torná-lo decifrável e, então, legitimar a leitura. Caso não haja essa correspondência, o texto não acontece e, por si só, não tem sentido algum. Muito além da concepção de pessoa, a figura do leitor é suplantada pela própria concepção de leitura:

Individualiza-se, pois, o processo de recepção, e não a figura do leitor: cada criação literária, na sua peculiaridade, suscita reações específicas. Que podem não ser pacíficas, dependendo da variação do modo como o produto artístico posiciona-se diante das normas vigentes, reproduzindo-as, criticando-as, parodiando-as ou renovando-as. Estabelece-se necessariamente um espaço entre o texto e seu acolhimento, intervalo que Jauss designa como "distância estética", medida - conforme o princípio de quanto maior, melhor - de onde procede ao valor da obra enquanto arte (ZILBERMAN, 2001, p. 89).

O livro-site de Angela Lago cumpre esse aspecto literário e, para ser compreendido, exige dos pequenos leitores uma singular cumplicidade nas interações. Assim, entre leitor e texto há um diálogo que oficializa a existência da própria autoria. A obra literária não fica limitada ao momento de produção, ainda que a atuação do autor seja um aspecto de grande significado. Na recepção do texto também é essencial o elemento estético, $o$ qual emerge da concretização produzida pelo leitor: "Daí segue: a obra literária tem dois polos que podem ser chamados polos artístico e estético" (ISER, 1996, p. 50). O papel do leitor é, então, crucial nos efeitos provocados pela obra:
[...] a obra é mais do que o texto, é só na concretização que ela se realiza. A concretização por sua vez não é livre das disposições do leitor, mesmo se tais disposições só se atualizam com as condições do texto. A obra literária se realiza então na convergência do texto com o leitor; a obra tem forçosamente um caráter virtual, pois não pode ser reduzida nem à realidade do texto, nem a disposições caracterizadoras do leitor (ISER, 1996, p. 50).

Enquanto o escritor é o responsável pela existência do texto, é o leitor aquele que atribui vida à matéria escrita, autenticando a existência do próprio autor:

[...] a marca do escritor não é mais do que a singularidade da sua ausência; é preciso que ele faça o papel de morto no jogo da escrita. [...] faz bastante tempo que a crítica e a filosofia constataram esse desaparecimento ou a morte do autor (FOUCAULT, 2009, p. 88).

Conforme Wolfgang Iser (1996, p. 51), apenas por meio de uma consciência receptora que o texto de fato se realiza e, para que isso ocorra, torna-se imprescindível a realização da leitura, pois nela a obra concebe seu caráter próprio enquanto processo. Dessa forma, a obra atinge primazia quando, em sua virtualização, estabelece uma relação com o leitor, sem se reduzir a uma técnica de representação. Com isso, a obra literária se preenche não só na estrutura textual, mas também na recepção que o leitor dá ao texto, o que implica o quanto ele é ou não afetado pela leitura realizada, enfim, qual a sua interação com a estrutura da obra. Isso é verificável na estruturação dada ao site literário de Angela Lago, o qual, para ser lido, dependerá da recepção do leitor. 
Um dos links da página principal do site de Angela Lago é o ABCD - brazilianABCDbrasileño -, o qual abre uma nova página que é carregada protocolarmente por palavras e imagens que vão se sucedendo: a palavra anjo é substituída por Angela. Nesse momento, um anjo literalmente desaba sobre a palavra Angela, fazendo surgir o sobrenome da autora - Lago -, do qual uma gota d'água cai e se transforma em um lago, onde o anjo se joga espalhando gotículas de letras pela tela do computador.

Continuando a experiência da leitura, ao passar o cursor sobre a menina-anjo, ela se ruboresce e uma cauda pontuda se desponta por baixo de seu vestido, a qual rapidamente é escondida pelo anjo - ou seria, por Angela? Mesmo desconhecendo o comentário que a escritora faz a respeito do próprio nome - "este diabo de nome" -, o leitor daria a sua atualização ao texto a partir da interação: "O observador pode considerar o objeto estético como incompleto, sair de sua atitude contemplativa e converter-se em co-criador da obra, à medida que conclui a concretização de sua forma e de seu significado" (JAUSS, 1979, p. 82). O paradoxo resultante dessa brincadeira com as imagens alavancaria, então, uma significação para a expressão anjo endiabrado. De um modo geral, fica evidenciada a importância do contexto para a sua recepção:

[...] a complexa interdependência que se estabelece entre o texto (objeto de análise e de reflexão) e o contexto que o elabora e o envolve (contexto interrogativo, contestatório, etc.) através do qual se realiza o pensamento do sujeito que pratica ato de cognição e de juízo. Há encontro de dois textos, do que está concluído e do que está sendo elaborado em reação ao primeiro. Há, portanto, encontro de dois sujeitos, de dois autores.

O texto não é um objeto, sendo por esta razão impossível eliminar ou neutralizar nele a segunda consciência, a consciência de quem toma conhecimento dele (BAKHTIN, 1992, p. 333).

\section{Procedimentos metodológicos}

O procedimento metodológico adotado foi uma pesquisa exploratória de caráter bibliográfico e interpretativo, que tomou como corpus um site composto por diversos links de literatura eletrônica direcionada ao público infanto-juvenil, de modo que possibilitasse a verificação da principal hipótese levantada: a ideia de que na literatura eletrônica os recursos tecnológicos digitais não exercem o papel de facilitadores da leitura, mas o de constituintes de uma manifestação nova textual que exige a mobilização da atenção e a interação globalizada dos sentidos do leitor. Também foi considerada como pressuposto que a intensa interatividade proporcionada pelo hiperlink pode fazer com que o leitor atribua mais relevância à sua movimentação pelo site do que à própria compreensão do texto.

O site utilizado para tal verificação foi angela-lago.net.br, mais especificamente o link ciberespacinho, e tomou-se como critérios as alterações textuais decorren- 
tes da mudança do suporte textual e a recepção do texto, bem como a ludicidade e a interatividade proporcionadas pela linguagem hipertextual e pelas ilustrações na dinâmica da literatura eletrônica infanto-juvenil.

Escolheu-se o site da escritora e ilustradora Angela Lago pela riqueza no emprego de distintos elementos semióticos, além de levar em consideração a relevância da referida artista para a literatura infanto-juvenil. São várias a suas premiações e vasta a relação de títulos ilustrados e escritos, mantendo no impresso e na web uma literatura que, na simplicidade do texto feito para crianças, se faz complexa. Tais elementos do site de Angela Lago possibilitaram a ampliação das discussões sobre o funcionamento do texto e da literatura eletrônica destinada ao jovem público leitor de palavras e de imagens.

\section{A caminho de uma ciberliteratura}

A oferta de textos digitais com aspecto literário no ciberespaço, como os produzidos por Angela Lago, ainda não constitui um número expressivo, mas se torna significativa quando aferida sob a potencialidade que a linguagem assume por meio dos recursos tecnológicos. Daí uma nova literatura: móvel, engendrada, instantânea, interativa e deslocalizada; uma literatura gerada e consumida no ciberespaço, de tal forma que é possível mixar em uma única mídia sons, ima- gens e palavras, atribuindo ao texto uma tipologia e uma concepção genuínas.

Em vez de um livro impresso, o leitor encontra um texto sem superfície, sem vestígios de volume. Tendo um site como suporte, o texto, hipertextualmente, abriga uma ou milhares de páginas, sob uma capacidade praticamente infinita de desdobramentos. A tela funciona como suporte para as narrativas audiovisuais que não deixam de contemplar as palavras - não obstante, um livro-site, uma ciberliteratura; a união do espaço virtual ao universo literário.

Nesse novo fazer literário, nem todo texto do meio digital se classifica como literatura eletrônica. Esse é um termo criado por Noah Wardrip-Fruin, crítico de literatura eletrônica e chefe da comissão da ELO (Eletronic Literature Organization), juntamente com sua equipe. Literatura eletrônica é definida, então, como "obra com aspecto literário importante que aproveita as capacidades e contextos fornecidos por um computador independente ou em rede" (HAYLES, 2009 , p. 21). Trata-se de uma literatura de caráter experimental e híbrido, correspondente às transformações nos modos perceptivos e cognitivos pelos quais a sociedade está passando em decorrência dos avanços tecnológicos. Estabelece-se, assim, uma distinção da literatura digitalizada, a qual se caracteriza pela transição do papel para o pixel, em termos puramente técnicos.

Sob a denominação de Infoliteratura ou Ciberliteratura, Pedro Barbosa (2003) 
também faz menção à literatura emergente na cibercultura como

[...] procedimento criativo novo, nascido com a tecnologia informática, em que o computador é utilizado, de forma criativa, como manipulador de signos verbais e não apenas como simples armazenador e transmissor de informação [...] (BARBOSA, 2003, p. 4).

Nessa perspectiva, o suporte eletrônico - não só o computador, mas, em um contexto mais recente, o tablet e o smartphone - extrapola a mera função de arquivo e veículo de informações para estabelecer inovadoras conexões com a Literatura:

[...] funciona como "máquina aberta", ou seja, uma máquina em que a informação de entrada ou input é diferente da informação de saída ou output (por oposição a "máquinas fechada", como é o caso de um gravador áudio ou vídeo, onde a informação de entrada é igual à informação de saída) (BARBOSA, 2003, p. 5).

Fica nítida, então, a profunda alteração que o suporte eletrônico instaura no circuito comunicacional do texto literário, de tal modo que a atuação do leitor se torna condição para a própria materialização do texto. Além disso, ao texto verbal grafado, são interligados elementos tradicionalmente dispersos, como a imagem animada e o som. A partir dessas construções textuais, tornam-se explicitas questões sobre a delineação dada ao texto literário eletrônico, não aspectos ligados ao fim ou não do livro impresso. A literatura infanto-juvenil propõe diferentes modos de interação com o leitor, seja em suportes impressos ou eletrônicos:
Tais modalidades não se excluem, tendo em vista que ambas estabelecem uma relação dialógica/intertextual/hipertextual no processo de composição de suas materialidades ou virtualidades (CARVALHO, 2010, p. 154-155).

As novas formas de criação literária que surgem a partir do espaço virtual criado pelas redes computacionais têm recebido muitos nomes. Entre essas nomenclaturas, Santaella (2012, p. 230-1), ao referir-se a Mourão (2001) e Costa Santos (2010), menciona: literatura gerada por computador, literatura informática, infoliteratura, literatura algorítmica, literatura potencial, ciberliteratura, literatura generativa, hiperficções, texto virtual, geração automática de texto, poesia animada por computador e poesia multimídia.

A (re) configuração da linguagem literária a partir de softwares faz com que o escritor, além do típico domínio da palavra, precise manipular a linguagem cibernética - razão que pré-determina parcerias entre escritores, programadores e designers gráficos -, gerando uma literatura experimental, cingida por um mosaico semiótico que articula pensamento humano e processamento computacional: "A conjunção da língua com o código tem estimulado experimentos na formação e na colaboração de diferentes tipos de linguagens" (HAYLES, 2009 , p. 36). Nessa nova literatura, as proficiências visual e gráfica se tornam tão necessárias quanto a verbal. 


\section{Considerações finais}

Ainda que se discuta muito sobre a permanência ou o desaparecimento do artefato livro devido ao desenvolvimento das tecnologias digitais, outras questões se tornam mais relevantes, como a leitura a partir do hipertexto e o protagonismo do leitor. Nessa perspectiva, encontra-se o site de Angela Lago, o qual ilustra a união entre literatura infantil e a internet, alocando o texto em um novo suporte que suscita questões em torno de sua forma de recepção.

Nesse território on-line não se dá uma leitura convencional, que impele o leitor para ações lineares. Nele as páginas se abrem por meio de hiperlinks e o leitor encontra-se estimulado a dar a sua própria sequência ao texto, com a liberdade de coautor. Não há a necessidade de fazer uma leitura unidimensional, mas o incentivo para torná-la o mais descontínua quanto o leitor determinar que tenha que ser - o que fica explícito em ciberespacinho. Assim, o texto que estava no plano virtual - das leituras em potencial - é atualizado pelo leitor, à medida que passa a receber sua interação.

A leitura no ciberespacinho de Angela Lago curiosamente evidencia uma interatividade física das palavras por meio dos recursos tecnológicos, acrescentando animação, som e deslocamentos hipertextuais. Nesse ambiente, transparece uma linguagem híbrida que dissociada da tecnologia digital não teria a mesma conotação e, ao contrário dos maus-pres- ságios contemporâneos, em angela-lago. net.br, a ausência do suporte de celulose não exclui da obra o seu caráter literário. Pelo contrário, somando-se à ludicidade, essa nova configuração representa mais uma vertente para a literatura infantil.

Produzido no ambiente digital, o texto digital em estudo continua sendo literário e exige do leitor atenção e interação que excedem os cliques de link em link. Nesse caso, seria incoerente discutir sobre superficialidades da leitura no suporte digital; em nada há simplificação ou facilitação do diálogo entre o texto digital de Angela Lago e o leitor. Importante, então, é expandir olhares para a recepção que o leitor dá à literatura eletrônica, evidenciando os processos de atualização pelos quais ele passa, não se distanciando do contexto enunciativo:

O todo do enunciado se constitui como tal graças a elementos extra-lingüísticos (dialógicos), e este todo está vinculado aos outros enunciados. $\mathrm{O}$ enunciado é inteiramente perpassado por esses elementos extra-lingüísticos (dialógicos) (BAKHTIN, 1997, p. 335-336).

Para que haja atualização, o livro-site de Angela Lago não exige apenas a familiaridade com os ambientes virtuais, mas a acuidade de um leitor que se pré-disponha à leitura intersemiótica de dois universos fantásticos: o da palavra e o da imagem. 
Ciberespacinho: the intersemiotic speech in the children and youth electronic literature

\section{Abstract}

This study aims to investigate the impact of new technologies of information and communication on the modes of production and reading of the text directed at children and youth, in view of the emergence of a fully electronic literature and a speech based on dialogue between the written word and the word-sonorous-drawn animated. For this, will be considered the site of writer and illustrator Angela Lake, angela-lago. net.br, especially the link called $c i$ berespacinhomyoldhtmlsite, observing their inter-semiotic speech and the appropriation of hypertext features enhanced by digital technology. It was noted that the electronic support does not extract the literary aspects of the text, but it leads to the use of a hybrid language, potentially hypermedia, that incorporates the genesis of the text without limiting the updates to be made by the reader.

Keywords: Literature. Reader. Technologies. Reception.

\section{Referências}

ANTONIO, Jorge Luiz. Sobre poesia digital. Disponível em: <http://arteonline.arq.br/museu/ensaios/ensaiosantigos/jlantonio.htm>. Acesso em: 14 maio 2014.

BABO, Maria Augusta. O hipertexto como nova forma de escrita. In: Süssekino, Flora (Org.) Historiografia literária e as técnicas da escrita: do manuscrito ao hipertexto. Rio de Janeiro: Vieira e Lent, 2003. p. 104-111.
BAKHTIN, Mikhail. Estética da criação verbal. São Paulo: Martins Fontes, 1997.

BARTHES, Roland. Crítica e verdade. São Paulo: Perspectiva, 2007. Disponível em: $<$ http://moodle.stoa.usp.br/file.php/1473/ RolandBarthes-CríticaeVerd.pdf $>$. Acesso em: 7 set. 2013.

CARVALHO, Diógenes Aires de. Literatura infanto-juvenil: diálogos entre a cultura impressa e a cibercultura. Desenredo - Revista do programa de Pós-Graduação em Letras da Universidade de Passo Fundo. Passo Fundo, v. 6, n. 2, p. 154-169, jul./dez. 2010. Disponível em: <http://www.upf.br/seer/index.php/rd/article/view/1715/1132>. Acesso: 20 ago. 2013.

CLÉMENT, Jean. Do livro ao texto: As implicações intelectuais da edição eletrônica. In: SÜSSEKINO, Flora. (Org.). Historiografia literária e as técnicas da escrita: do manuscrito ao hipertexto. Rio de Janeiro: Vieira e Lent, 2003. p. 28-35.

CHARTIER, Roger. A ordem dos livros: leitores, autores e bibliotecas na Europa entre os séculos XIVe XVIII. Brasília: Editora Universidade de Brasília, 1999.

FOUCAULT, Michel. Estética: Literatura e Pintura, Música e Cinema. Rio de Janeiro: Editora Forense Universitária, 2009.

HAYLES, N. Katherine. Literatura eletrônica: novos horizontes para o literário. São Paulo: Global, 2009.

IZER, Wolfgang. $O$ ato da leitura. São Paulo: Editora 34, 1996.

$\mathrm{KOCH}$, Ingedore Grunfeld Villaça. Desvendando os segredos do texto. São Paulo: Cortez, 2005.

LAGO, Angela. Ciberespacinho. Disponível em: http://www.angela-lago.com.br/index1. html. Acesso em: 02 out. 2013.

LEJEUNE, Philippe. O pacto autobiográfico: de Rousseau à internet. Belo Horizonte: UFMG, 2008. 
LÉVY, Pierre. Cibercultura. São Paulo: Editora $34,1999$. 34, 1996. O que é virtual? São Paulo: Editora

MARCUSCHI, Luiz Antônio. O hipertexto como um novo espaço de escrita em sala de aula. In: AZEVEDO, José Carlos de (Org.). Língua portuguesa em debate: conhecimento e ensino. Petrópolis-RJ: Vozes, 2000. p. 87-111.

MARCUSCHI, Luiz Antônio; XAVIER, Antônio Carlos. Hipertexto e gêneros digitais. 2. ed. Rio de Janeiro: Lucerna, 2005.

MOURÃO, José Augusto. A criação literária por computador. 2001. Disponível em: http:// www.triplov.com/creatio/mourao.htm. Acesso em 22 maio 2014.

PRENSKY, Marc. Digital Natives, Digital Immigrants. MCB University Press, 2001. Disponível em: <http://www.marcprensky. com/writing/Prensky $\% 20 \% 20$ Digital $\% 20$ Natives, \%20Digital\%20Immigrants\%20\%20 Part1.pdf>. Acesso em: 21 out. 2013.

SANTAELLA, Lúcia. O que matrix não mostra: o corpo sensório-perceptivo do cibernauta. In: LYRA, Bernadete; SANTANA, Gelson (Orgs.). Corpo e mente. São Paulo: Arte e Ciência, 2003. p. 77-93.

SANTAELlA, Lúcia. Para compreender a ciberliteratura. Texto Digital. Florianópolis, v. 8, n. 2, p. 229-249, jul./dez. 2012. Disponível em: <http://periodicos.ufsc.br/ index.php/textodigital/article/view/1807-9288.2012v8n2p229>. Acesso em: 27 abr. 2014.

SANTOS, Cinthya Costa. Literatura Digital: Intertexto, Intratexto e Hipertexto. In: $2^{\circ}$ Encontro de Ciência da Literatura, da Faculdade de Letras da UFRJ, 21 a 23 de outubro de 2002. Disponível em http://www. letras.ufrj.br/ciencialit/index_encontro.htm, Acesso em: 10 jul. 2014.

SCHITTINE, Denise. Blog: comunicação e escrita íntima na internet. Rio de Janeiro: Civilização Brasileira, 2004.
VILLAÇA, Nízia. Impresso ou eletrônico: um trajeto de leitura. Rio de Janeiro: Mauad, 2002.

XAVIER, Antônio Carlos dos Santos. Hipertexto na sociedade da informação: a constituição do modo de enunciação digital. 2002. Tese (Doutorado em Linguística) - Universidade Estadual de Campinas, Instituto de Estudos da Linguagem. Campinas-SP, 2002.

ZILBERMAN, Regina. Fim dos livros, fim dos leitores?. São Paulo: Senac, 2001.

ZILBERMAN, Regina. Que literatura para a escola? Que escola para a literatura? Desenredo - Revista do programa de Pós-Graduação em Letras da Universidade de Passo Fundo. Passo Fundo, v. 5, n. 1, p. 9-20, jan./ jun. 2009. Disponível em: <http://www.upf.br/ seer/index.php/rd/article/view/1715/1132>. Acesso: 20 ago. 2013. 